\title{
STRATEGI REHABILITASI PENYALAHGUNA NARKOTIKA MELALUI PENDEKATAN KEAGAMAAN \\ (Studi Kasus di Pondok Pesantren Al-Qodir Cangkringan Sleman)
}

\author{
Mirza Maulana Al-Kautsari \\ Konsentrasi Social Work, Prodi Interdisciplinary Islamic Studies (IIS), Progam Pascasrjana UIN \\ Sunan Kalijaga Yogyakarta \\ Email: Mirza.maul@gmail.com
}

\begin{abstract}
ABSTRAK
Dalam penelitian ini menggunakan metode penelitian Kualitatif dan dilatarbelakangi dengan meningkatnya penyalahguna dikalangan remaja yang tentunya dapat merusak perkembangan tumbuh kembang dan masa depannya. Oleh kerana itu perlu dilakukan sebuah pendekatan khusus untuk menghilangkan kebiasaan penggunaan narkotika dalam bentuk rehabilitasi sosial. Fokus penelitian adalah untuk mendeskripsikan konsep dan aktifitas rehabilitasi perspektif keagamaan di Pondok Pesantren Al-Qodir Cangkringan Sleman yang berdampak kepada penyembuhan bagi para santri. Metode penelitian yang digunakan dalam penelitian ini adalah wawancara, dokumentasi, observasi dan analisis data dengan teori Miles dan Huberman. Hasil dari penelitian ini menjabarkan bahwa konsep Rehabilitasi perspektif agama memiliki banyak kesamaan dalam teori rehabilitasi secara umum, terdapat proses medis dan sosial. Dalam rehabilitasi pandangan agama lebih ditekankan aspek rohaniah, sehingga diharapkan pasien juga mengerti kewajiban menjadi orang yang beriman. Sedangkan proses rehabilitasi yang dilakukan di Pondok Pesantren Al-Qodir dalam bentuk kegiatan sehari-hari seperti dengan Terapi Mandi, Terapi Sholat Dan Dzikir, Terapi Peralihan Dan Terapi Mujahadah.
\end{abstract}

Kata Kunci: Rehabilitasi, Keagamaan, Pondok Pesantren.

\begin{abstract}
In this study using Qualitative research methods and the background of the increasing number of abusers among adolescents, which of course can damage the development of growth and future. Therefore, a special approach is needed to eliminate the habit of using narcotics in the form of social rehabilitation. The focus of the study is to describe the concept and rehabilitation activities of a religious perspective at Cangkringan Al-Qodir Islamic Boarding School which has an impact on healing for the santri. The research method used in this study was interviews, documentation, observation and data analysis with the theory of Miles and Huberman. The results of this study illustrate that the concept of rehabilitation of religious perspectives has many similarities in the theory of rehabilitation in general, there are medical and social processes. In rehabilitation, the view of religion emphasizes the spiritual aspect, so that the patient is expected to also understand the obligation to be a believer. While the rehabilitation process is carried out in Al-Qodir Islamic Boarding School in the form of daily activities such as Bath Therapy, Prayer and Dhikr Therapy, Transitional Therapy and Mujahadah Therapy.
\end{abstract}

Keywords: Rehabilitation, Religion, Islamic Boarding School. 


\section{A. PENDAHULUAN}

Perkembangan penduduk di negara Indonesia sangatlah pesat, didukung dengan perkembangan teknologi dan informatika. Pertumbuhan masyarakat dalam segi teknologi sangatlah beragam dari mulai penggunaan alat komunikasi, alat transportasi hingga pendidikan yang berbasis internasional. Dinamakan fenomena ini dengan globalisasi, ciri khusus dari istilah ini adalah dimana batasan geografi seseorang semakin dekat, artinya mudahnya melakukan komunikasi dari daerah yang jauh sekalipun. Tidak sedikit dampak dari globalisasi membuahkan pengaruh yang negatif dalam kehidupan, khususnya dikalangan para remaja.

Pertumbuhan remaja di Indonesia ini sangatlah signifikan, istilah remaja sudah dapat diberikan kepada anak yang baru lulus Sekolah Dasar (SD), bahkan ada yang masih dalam pendidikan SD. Melihat kejadian ini seorang pendidik dan orang tua semakin was-was atau gelisah dalam memantau anak-anaknya agar tidak terbawa dipergaulan bebas, salah satunya pengaruh "Napza". Dewasa ini banyak sekali dikalangan remaja yang terjebak di dalam narkotika, walaupun tidak menutup kemungkinan bahwa dikalangan dewasa juga banyak yang terjerumus dalam obat tersebut.

Narkoba dan Napza sering kita dengar ditelinga kita, hal ini sudah men jadi sorotan nasional untuk membrantas penyebaran obat tersebut. Sebelum melangkah kepada proses penanggulan yang dilakukan oleh keluarga,

${ }^{1}$ Eko Prasetyo, Mengapa Seorang Pecandu Harus Di Rehabilitasi, presentasi pada tanggal 20 Desember 2015. lembaga, organisasi dan pemerintah, ada baiknya marilah kita mengetahui apa itu narkoba, napza, dan penggunaanya.

Narkoba mempunyai susunan Narkotika, Psikotropika, Bahan adiktif. Sedangkan Napza memiliki susunan Narkoba, Alkohol, Psikotropika, Zat adiktif. Secara sekilas tampak sama, namun didalam kajian Napza memasukan alkohol sebagai bagian darinya, maka dari itu yang perlu menjadi bahan perhatian bahwa ketergantungan terhadap alkohol dalam tingkat tertentu juga menjadi sorotan publik untuk dilakukan pencegahan. ${ }^{1}$

Unsur dari obat tersebut memiliki zat yang dinamakan adiktif, dalam kajian ilmiah disebut adiksi. Adiksi sendiri memiliki pengertian suatu proses ketergan tungan terhadap sesuatu atau obat yang memberikan efek untuk melakukannya kembali. Ketergantungan ini yang menjadi berbahaya dalam penggunaan obat tersebut, karena jikalau digunakan dalam dosis yang besar akan meng akibatkan kerusakan dalam organ tubuh manusia. Tidaklah wajar mengapa narkotika ataupun napza ini menjadi sorotan kritis dalam pergaulan remaja.

Istilah narkoba sebenarnya muncul ditengah-tengah masyarakat untuk mengingat-ingat dari sebuah istilah narkotika dan obat-obat berbahaya dan terlarang. Secara umum narkoba itu singkatan Narkotika dan obat-obat berbahaya lainya, bahan-bahan ini juga termasuk didalamnya zat-zat kimia, limbah beracun, pestisida atau lain-lainya. ${ }^{2}$ Fatwa

\footnotetext{
${ }^{2}$ Heriadi Willy, Brantas Narkoba Tak Cukup Hanya Bicara, (Yogyakarta: UII Press, 2005), hlm 4.
} 
Majlis Ulama Indonesia (MUI) tentang penyalahgunaan Narkotika tanggal 10 Shafar 1396 H/10 Februari 1967 M, menyatakan haram hukumnya penyalahgunaan Narkotika, karena mem bawa kemadaratan yang mengakibatkan mental dan fisik seseorang serta terancamnya keselamatan masyarakat dan Ketahanan Nasional. ${ }^{3}$

Seseorang ketika sudah mulai mengenal narkoba akan terlihat dari beberpa tahapan, terlihat dari tahap awal, dimulai dengan perasaan ingin tahu terhadap obat tersebut. Dari hal itulah menjadi benar terdapat faktor lingkungan, contohnya teman-teman, seringkali orang terjerumus kedalam sebuah dunia perobatan, dikarenakan dari rasa ingin tahu dan ajakan teman. Setelah itu seseorang mulailah mencoba hal tersebut dengan berusaha membangun stigma "Sedikit tak apa-apa" itulah menjadi gerbang awal seseorang terjerumus dalam obat yang dinamakan narkoba.

Akhirnya masuklah seseorang tersebut dalam dunia narkoba, dari sekali dan memunculkan rasa ketagihan. Itulah yang dinamakan adiksi, efek dari obat tersebut sangatlah kuat dan memiliki pengaruh untuk mencoba berkali-kali. Jikalau seseorang tersebut tak dapat memilikinya akan berdampak negatif dalam diri fisik maupun psikis, dinamakan dengan 'Sakaw'. Efek ini banyak muncul ketika seseorang ingin melakukannya kembali, terkadang fisiknya menjadi sakit, menggigil dan gatal-gatal, selain itu dari segi psikis seseorang akan merasa was-was, gelisah, depresi dan suram dalam pikirannya. Itulah yang dinamakan ketergantungan.

Kesenangan dan kenyamanan ketika menggunkan obat tersebut menjadi mo tivasi seseorang untuk mengonsumsi obat terlang tersebut. Bersandar dari kejadian yang kita namakan Sakaw tersebut, menjadi alasan seseorang untuk berusaha mendapatkan bahkan taruhanya nyawa. Ironisnya para bandar-bandar narokoba memanfaatkannya dengan memasang tarif yang tinggi, sehingga efek yang ditimbulkannya sangatlah beragam bagi seseorang yang terjangkit. Tugas kita sebagai "Agent of Change" adalah bagaimana melakukan rehabilitasi kepada pecandu narkoba?

Proses rehabilitasi ini sangatlah beragam dari mulai rehabilitasi medis dan sosial. Rehabilitasi medis merupakan tahap awal setiap seseorang melakukan rehabilitasi, karena cara ini memang wajib dilakukan setiap penyembuhan. Tahap medis merupakan tahap pembersihan racun, zat berbahaya yang ada didalam tubuh seseorang yang sering dinamakan dengan "Detoksifikasi". Proses ini merupakan tahap yang amat mudah dalam tahap rehabilitasi, sedangkan tahap yang rumit adalah rehabilitasi dalam tahap sosialnya.

Rehabilitasi sosial merupakan penentu dari kesembuhan seseorang dari kecanduan narkoba, karena dari pengo batan medis saja tanpa rehabilitasi sosial mempunya tingkat kambuh lebih tinggi. Kesembuhan seseorang tidak hanya ditentukan oleh ketika dia menggunakan obat tersebut namun penyebab dari seseorang masuk

${ }^{3}$ Badan Narkotika Nasional, Narkotika Dalam Pandangan Agama, (Jakarta: BNN,2012), hlm 19. 
dalam dunia narkoba. Masalah apa yang ada dalam dirinya sehingga dia menggunakan obat tersebut. Pengkajian tersebut yang ada dalam proses rehabilitasi sosial.

Penyebab seseorang menggunakan narkoba sangatlah penting, karena salah satu prinsip utama dalam rehabilitasi adalah bukan bagaimana seseorang menggunakan obat tersebut, namun mengapa bisa terjerumus dalam dunia narkoba. Jikalau alasan seseorang me lakukan narkoba karena depresi, frustasi atau kekecewaan dalam keluarga, maka hal itulah yang perlu disembuhkan dan dikompromikan dengan pendamping atau pekerja sosial. Namun jikalau alasan melakukan karena hanya penasaran maka untuk tahap rehabilitas jangan sampai mendekati tempat, teman dan obat itu sendiri.

Rehabilitasi sosial merupakan sebuah proses pemberian keterampilan supaya dia tidak kambuh lagi dalam ketergantungan narkoba. Keterampilan tersebut meliputi beberapa ruang lingkup mengenai kekuatan dalam sendiri untuk sembuh, dukungan keluarga untuk selalu mengingatkan dan mendukung, serta masyarakat yang mampu menerima keberadaannya.

Terdapat beberapa intervensi dalam proses rehabilitasi sosial ini yaitu dengan bimbingan fisik dengan cara dilatih berketrampilan atau mengalihkan ke hobi seseorang. Proses tersebut memberikan wujud pengalihan pikiran untuk tidak mudah goyah kembali ke dunia yang telah dia lewati. Untuk memberikan ketenangan dalam jiwa seseorang yang sedang menjalani rehabilitasi, harus diberikan

${ }^{4}$ Profil Pondok Pesantren Al-Qodir Cangkringan Sleman, dikutip pada tanggal 1 Januari 2016. bimbingan keagamaan seseuai agama yang mereka yakini. Kontrol agama sangatlah penting, karena didalam agama mampu meberikan ketenangan dan kecerahan dalam berfikir.

Usaha rehabilitasi yang dilakukan pemerintah berupa pendirian instansi yang sering disebut Badan Narkotika Nasional (BNN). Usaha ini juga diperjuangkan oleh pekerja sosial sebagai tugas mulia dengan mendirikan lembaga yang menampung bagi para pecandu narkoba, khususnya di Yogyakarta. Di Daerah Istimewa Yogyakarta ini banyak lembaga yang menangani masalah tersebut. Lembaga penanggulangan ada yang berwujud Pondok Pesantren ataupun Panti asuhan, diantaranya lembaga Pondok Pesantren Al Qodir di daerah Cangkringan, Sleman, Yogyakarta.

Salah satu pesantren yang dipandang cukup unik adalah Pesantren Salafiyah Al Qodir yang terletak di Cangkringan, Sleman. Dalam buku "Pondok Pesantren Al Qodir, Menembus Batas" dijelaskan, bahwasannya pondok ini dirintis pendiriannya oleh KH. Masrur Ahmad MZ pada tahun 1980an dan sejak tahun 1990 para santri sudah mulai berdatangan. Namun, baru tahun 1998 secara resmi tercatat dan terdaftar di Departemen Agama RI. ${ }^{4}$

Pesantren Al Qodir memiliki nilai tambah sendiri jika dibandingkan dengan pesantren lain, yaitu menjadi tempat rehabilitasi para pecandu narkoba. Di Indonesia sendiri pesantren yang menerapkan terapi penyembuhan para pecandu narkoba tidaklah banyak. Setelah 
mengetahui beberpa penjelasan, maka sudahlah cukup untuk melakukan kajian yang lebih mendalam tentang bagaimana konsep dan proses rehabilitasi Penyalah gunan Narkoba Pendekatan Keagamaan di Ponpes Al-Qodir"

Untuk mengetahui kebaharuan dan keaslian penelitian, maka perlu disajikan berbagai hasil penelitian terdahulu yang fokus penelitiannya berkaitan dengan penelitian ini. Beberapa penelitian ini adalah: Penelitian milik "Taufik Rahmansyah" yang berjudul Studi Tentang Materi Dan Metode Pelayanan Bimbingan Islami Di Pondok Pesantren Al-Qodir Tanjung Wukirsari Cangkri ngan Sleman. Penelitian ini menggunakan pendekatan kualitatif. Sedangkan Penelitian ini memiliki fokus terhadap materi dan pengajaran apa saja yang diterapkan di Ponpes Al-Qodir dalam bentuk kegiatan sehari-hari. Penelitian lain adalah milik "Efrida Yanti Rambe" yang berjudul Keberagaman Remaja Penyalahguna Narkotika (studi Kasus Pada Penganut Beda Agama Di Pondok Pesantren Al Qodir Sleman, Yogyakarta. Penelitian ini menggunakan pendekatan kualitatif. Sedangkan fokus penelitian ini adalah tentang pengetahuan dan kegiatan agama para remaja yang ada di Ponpes Al-Qodir.

Dari penelitian-penelitian tersebut, menunjukan bahwa penelitian ini yang berjudul Rehabilitasi Penyalahguna Narkoba Pendekatan Keagamaan di Pondok Al-Qodir sejauh ini layak untuk diteliti, karena sejauh ini belum ada penelitian yang

${ }^{5}$ Suharsimi Arikunto, Prosedur Penelitian: Suatu Pendekatan Praktek, (Jakarta: Rineka Cipta, 2006), hlm 142. memiliki fokus yang sama, yaitu proses rehabilitasi yang dilakukan di Pondok Pesantren Al-Qodir.

Penelitian tentang Rehabilitasi Penyalahguna Narkoba perspsektif Agama ini menggunakan pendekatan penelitian kualitatif. Penelitian ini menggunakan studi yang juga sering disebut dengan penelitian lapangan (fild research). Penelitian studi adalah suatu penelitian yang dilakukan secara intensif terinci dan mendalam terhadap suatu organisasi, lembaga atau gejala tertentu. Ditinjau dari wilayah garapannya, maka penelitian kasus ini hanya meliputi daerah atau subyek yang sangat sempit, tetapi bila ditinjau dari sifat penelitiannya, mempunyai kasus yang lebih mendalam. ${ }^{5}$

Dalam penelitian "Rehabilitasi Penyalahguna Narkoba Pendekatan Keagamaan di Pondok Pesantren Al-Qodir Cangkringan Sleman" memiliki obyek penelitian yaitu Kyai atau pengasuh pesantren, Pengurus pesantrem, Rohaniawan dan Santri-santri yang mengikuti rehabilitasi. Cara pemilihan informan dengan memilih santri yang ikut progam rehabilitasi dalam kegiatan yang sedang dilakukan, pemilihan kyai atau pengasuh dengan berkunjung ke rumah kyai sedangkan untuk rohaniawan dipilih yang sudah lama tinggal ditempat tersebut (Senior).

Untuk memperoleh data yang obyektif dan dapat dipertanggung jawabkan secara ilmiah, diperlukan metode yang mampu mengungkap data sesuai dengan pokok 
permasalahan. Metode yang digunakan dalam penelitian ini adalah wawancara, observasi dan dokumentasi. ${ }^{6}$ Dalam proses pengambilan data langkah-langkah yang dilakukan yaitu penyusunan, penjelasan, dan kemudian penganalisisan. Langkah ini dilakukan agar data yang ada tidak hanya sekedar mendeskripsikan fakta-fakta di lapangan.

\section{B. Tinjauan Umum Tentang Narkotika}

Istilah "narkoba" adalah singkatan dari narkotika dan obat/bahan berbahaya. Lama kelamaan disadari bahwa kepanjangan narkoba tersebut keliru sebab istilah obat "berbahaya" dalam ilmu kedokteran adalah obat-obatan yang tidak boleh dijual bebas, karena pemberiannya dapat membahayakan bila tidak melalui pertimbangan medis. Banyak jenis narkotika dan psikotropika memberi manfaat yang besar bila digunakan dengan baik dan benar dalam bidang kedokteran. Bahan-bahan berbaya yang termasuk didalamnya zat-zat kimia, limbah beracun, pestisida atau lain-lainya. ${ }^{7}$

Selain "narkoba", istilah lain yang diperkenalkan khususnya oleh Departe men Kesehatan Republik Indonesia adalah "NAPZA" atau "NAZA" yang merupakan singkatan dari Narkotika, Psikotropika dan Zat Adiktif. Narkoba merupakan bahan/zat yang bila masuk kedalam tubuh akan mempengaruhi tubuh terutama susunan syaraf pusat/otak sehingga jika disalahgunakan akan menyebabkan

${ }^{6}$ Suharsimi Arikunto, Prosedur Penelitian, HIm. 26.

${ }^{7}$ Heriadi Willy, Brantas Narkoba Tak Cukup Hanya Bicara, (Yogyakarta: UII Press, 2005), hlm 4. gangguan fisik, psikis/jiwa, depresi, perasaan bersalah dan fungsi sosial. ${ }^{8}$

Narkoba mempunyai susunan Narkotika, Psikotropika, Bahan adiktif. Sedangkan Napza memiliki susunan Narkoba, Alkohol, Psikotropika, Zat adiktif. Secara sekilas tampak sama, namun didalam kajian "Napza" memasukan alkohol sebagai bagian darinya, Maka dari itu yang perlu menjadi bahan perhatian bahwa ketergantungan terhadap alkohol dalam tingkat tertentu juga menjadi sorotan publik untuk dilakukan pencegahan. $^{9}$

Perlu mendapat perhatian khusus mengenai penjelsan "Zat Adiktif" yang merupakan bagian dari komponen narkoba. Secara harfiah adiksi memiliki pengertian suatu kondisi yang mengalami ketergantungan terhadap zat-zat adiktif berupa obat ataupun semacamnya sehingga memunculkan pengaruh kuat untuk selalu mengkonsumsinya. Sehingga merokok dalam sebuah kajian merupakan kondisi adiksi sehingga perlu diperhatikan pemakainnya, karena menurut penelitian merokok pembunuh ketiga setelah jantung koroner dan kanker.

Ada juga pembagian narkotika menjadi dua golongan, yaitu pertama meliputi bahan-bahan yang berasal dari tanaman, atau hasil pemrosesan dari pada: opiat (opium, morfin, heroin), kokain, dan cannabis (ganja). Kedua zat-za hasil kimiawi sintetis yang berupa "psychotropic
${ }^{8}$ Balai Rehabilitasi Narkoba, Tinjauan Rehabilitasi Narkoba, (Yogyakarta: Kunci, 2015), hlm 11.

${ }^{9}$ Eko Prasetyo, Mengapa Seorang Pecandu Harus Di Rehabilitasi, presentasi pada tanggal 20 Desember 2015. 
substances" (depressants, stimulants, hallucinogen $)^{10}$.

Semua zat yang termasuk NAZA menimbulkan efek adiksi (ketagihan) yang pada gilirannya berakibat pada dependensi (ketergantungan). Zat yang termasuk NAZA memiliki sifat sebagai berikut:

1. Keinginan yang tak tertahankan (an over powering desire) terhadap zat yang dimaksud, dan kalau perlu dengan jalan apapun untuk memperolehnya.

2. Kecenderungan untuk menambah takaran (dosis) sesuai dengan toleransi tubuh.

3. Ketergantungan psikologis, yaitu apabila pemakaian zat dihentikan akan menimbulkan gejala - gejala kejiwaan seperti kegelisahan, kecemasan, depresi dan sejenisnya.

4. Ketergantungan fisik, yaitu apabila pemakaian zat dihentikan akan menimbulkan gejala fisik yang dinamakan gejala putus zat. ${ }^{11}$

Melihat dampak ataupun efek yang ditimbulkan ketika menggunakan obat-obat berbaha tersebut maka perlu adanya perhatian khusus baik berupa pelarangan dan penanggulangan (rehabilitasi). Rehabilitasi merupakan fasilitas yang sifatnya semi tertutup, maksudnya hanya orang - orang tertentu dengan kepenti ngan khusus yang dapat memasuki area ini. Rehabilitasi narkoba adalah tempat yang memberikan pelatihan keterampilan dan pengetahuan untuk menghindarkan diri dari narkoba. ${ }^{12}$

Menurut UU RI No. 35 Tahun 2009, ada dua jenis rehabilitasi, yaitu: Rehabilitasi Medis merupakan suatu proses kegiatan pengobatan secara terpadu untuk membebaskan pecandu dari ketergantungan narkotika; Rehabilitasi Sosial terkait suatu proses kegiatan pemulihan secara terpadu, baik fisik, mental maupun sosial, agar bekas pecandu narkotika dapat kembali melaksanakan fungsi sosial dalam kehidupan masya rakat. ${ }^{13}$

Dalam proses rehabilitasi perlunya memperbaiki dan mengevaluasi daya guna dan hasil guna dari fasilitas rehabilitasi, sehingga konsep dan rencana yang diformulasikan dapat mencapai sasaran. Adapun upaya yang dilakukan anatara lain:

a. Memperbaiki dan meningkatkan kualitas dari petugas pelaksana dalam bidang pengobatan, rehabilitasi dan upaya penanggulangan narkotika.

b. Perlu diformulasikan pedoman dalam pengobatan dan penegak hukum.

c. Memonitor problem "kekambuhan" dan "terapi" melalui progam evaluasi.

d. Perlu diadakan penelitian dalam pengobatan, rehabilitasi dan upaya penanggulangan narkotika. ${ }^{14}$

\footnotetext{
${ }^{10}$ Andre Bossard, "Drug Traffickers: Multiple Profiles” dalam Ed Dennies Rowe Internasional Drug Trafficking, (Chicago: OICJ, 1988), hal 48.

${ }^{11}$ Balai Rehabilitasi Narkoba, Tinjauan Rehabilitasi Narkoba, (Yogyakarta: Kunci, 2015), hlm 11.
} 


\section{Konsep Rehabilitasi Penyalahguna Narkotika Perspektif Keagamaan}

Proses penanggulangan penyalah guna narkoba merupakan kajian yang butuh pemikiran mendalam terkait konsep dan praktik di lapangan. Sangat banyak sehingga menjadi komplek dalam tahap rehabilitasi melihat tantangan dari luar maupun dalam, namun tidak menjadi alasan untuk menyerah melihat konsep dasar terkait kepentingan kesehatan, ilmu pengetahuan serta pemberantasan narkoba

Sebagaimana telah diatur dalam Undang-Undang Narkotika Nomor 35 Tahun 2009 (UU No.35 tahun 2009) memiliki tujuan ketersediaan kepentingan kesehatan dan ilmu pengetahuan, pencegahan penyalahgunaan narkotika, serta pemberantasan peredaran gelap narkotika. Penegakan hukum terhadap tindak pidana narkotika telah banyak dilakukan oleh aparat penegakan hukum dan telah banyak mendapatkan putusan hakim di sidang pengadilan. Penegakan hukum ini diharapkan dapat menangkal merebaknya peredaran perdagangan narkotika. ${ }^{15}$

Rehabilitasi mendapat dukungan penuh dari pemerintah dalam hal pengentasan penyalahguna narkoba, baik melalui hukum pidana maupun proses rehabilitasinya. Sebagaimana upaya ini diberikan dalam konsep keagamaan, melihat begitu rumitnya masalah ini agama Islam memandang perlu menjaga kesehatan dan ketentraman bagi seluruh umat (Rahmatan Lil Alamin). Maka agama Islam sangat menjunjung tinggi

\footnotetext{
${ }^{15}$ Undang-Undang No. 35 Tahun 2009 Tentang Narkotika.

${ }^{16}$ Departemen Agama RI, AL-Qur'an dan Terjemahnya, (Jakarta: PT Sygma Examedia, 2009), hlm 25.
}

hidup sehat karena dalam hidup sehat terdapat jiwa yang kuat dan dapat mendukung seluruh aktivitas manusia dalam upaya mewujudkan kesejahteraan dan kebahagiaan dalam kehidupan lahir dan batin. Oleh karena itu menjaga kesehatan hukumnya wajib dan melarang kepada makan atau minuman yang merusak kesehatan.

Sebagaimana firman Allah dalam AlQur'an surat Al-Baqarah ayat 168, dalam terjemahnya sebagai berikut:

"Hai sekalian manusia, makanlah yang halal lagi baik dari apa yang terdapat di bumi, dan janganlah kamu mengikuti langakah-langakah syaitan, karena sesungguhnya syaitan itu adalah musuh yang nyata bagimu"16

Pelarangan penggunaan narkoba juga didukung melalui fatwa Majlis Ulama Indonesia (MUI) tentang penyalahguna narkoba tanggal 10 Shafar 1396 H/10 Februari 1976, menyatakan haram hukumnya penyalahguna narkotika, karena membawa kemadaratan yang mengakibatkan mental dan fisik seseorang serta terancamnya keselamatan masyarakat dan Ketahanan Nasional. ${ }^{17}$

Dalam konsep Islam sebuah proses rehabilitasi lebih dikenal dengan istilah terapi, dengan menggunakan prinsip "Berobat" dan "Bertaubat". Berobat berarti pasien menjalani proses pembersihan diri (Detoksifikasi) dari racun obat terlarang, sedangkat berataubat memiliki makna memohon ampun atas segala kesalahan

\footnotetext{
${ }^{17}$ Badan Narkotika Nasional, Narkotika Dalam Pandangan Agama, (Jakarta: BNN, 2012), hlm 19.
} 
kepada Allah SWT dan berjanji tidak akan mengonsumsi obat terlarang kembali. ${ }^{18}$

Peserta rehabilitasi (para santri) akan diasuh dan dibimbing oleh kyai (Rohaniawan), yang telah mendapatkan pendidikan dalam hal penanganan bagi penyalahguna narkoba dengan rasio satu kyai untuk sepuluh santri. Sedangkan psikoterapi memiliki rasio satu psikiatri untuk lima belas santri. Selain ditangani oleh dokter umum didampingi dengan psikolog dengan tes psikologinya, perlu tanaga ahli (Sosial Worker) dalam bimbingan keterampilan dan fungsi sosialnya. $^{19}$

Sehingga diharapkan dengan partisipasi dari para ahli dari dokter umum, rohaniawan, psikiater dan sosial worker dapat diharapkan pasian menjadi lebih cepat dalam kesembuhan melalu proses rehabilitasi yang solid.

\section{Gambaran Umum Pondok Pesantren Al- Qodir Cangkringan Sleman}

\section{Pondok pesantren}

Al-Qodir

Cangkringan terletak di Dusun Tanjang, Kelurahan Wukirsari, Kecamatan Cang kringan Kabupaten Sleman Yogyakarta. Salah satu pesantren yang dipandang cukup unik adalah Pesantren Salafiyah Al Qodir yang terletak di Cangkringan, Sleman. Dalam buku "Pondok Pesantren Al Qodir, Menembus Batas" dijelaskan,

Pondok ini dirintis pendiriannya oleh KH. Masrur Ahmad MZ pada tahun 1980an dan sejak tahun 1990 para santri sudah mulai berdatangan. Namun, baru tahun 1998

\footnotetext{
${ }^{18}$ Dadang Hawari, Terapi (Detoksifikasi) dan Rehabilitasi (Pesantren) Mutakhir Pasien Naza, (Jakarta: UI Press, 2008), hlm 1.
}

secara resmi tercatat dan terdaftar di Departemen Agama RI. Aktifitas Pesantren Al Qodir tidak jauh beda dengan aktifitas di Pondok Pesantren salaf pada umumnya, yaitu pengajian Al Qur'an dan kitab-kitab kuning. ${ }^{20}$

Pesantren Al Qodir memiliki nilai tambah sendiri jika dibandingkan dengan pesantren lain, yaitu menjadi salah tempat rehabilitasi para pecandu narkoba. Di Indonesia sendiri pesantren yang menerapkan terapi penyembuhan para pecandu narkoba tidaklah banyak. Sedangkan menurut pengakuan KH. Masrur Ahmad MZ atau biasa dipanggil Gus Masrur, terapi yang diterapkan di pesantrennya bukanlah berdasar agama, tapi berdasarkan hukum alam. Bahwasannya di balik setiap kesenangan ada kesulitan yang mengintai, dan di balik setiap kesusahan akan ada kemudahan yang menyertainya. Meskipun bukan berdasar agama tetapi sudah banyak para pecandu narkoba yang nyantri di Al-Qodir akhirnya sembuh.

Adanya Pesantren Al Qodir sebagai salah tempat rehabilitasi pecandu narkoba dirasa sangat strategis mengingat jumlah pengguna narkoba setiap tahunnya mengalami kenaikan. Menurut hasil penelitian Badan Nasional Narkotika (BNN) dengan Pusat Penelitian Kesehatan Universitas Indonesia periode 2011 menunjukkan angka prevalensi penyalah gunaan narkoba sebesar 2,2 persen atau setara dengan 3,8-4,2 juta orang dan diprediksi tingkat prevalensi pada 2015 akan mencapai 2,8 persen atau setara dengan 5,1

\footnotetext{
${ }^{19}$ Ibid., hlm 21.

${ }^{20}$ Profil Pondok Pesantren Al-Qodir Cangkringan Sleman, dikutip pada tanggal 1 Januari 2016.
} 
juta orang. Bahkan untuk tahun 2013 menurut Kepala BNN, Komisaris Jenderal Anang Iskandar, mengatakan bahwa 4 juta orang Indonesia sudah menggunakan narkoba dengan berbagai jenis dan berbagai cara. $^{21}$

Pondok Pesantren Al-Qodir Cangkringan Yogyakarta mempunyai visi dan misi yaitu menyembuhkan orang yang terkena gangguan jiwa dengan cara yang humanis, karena kyai menilai setiap manusia mempunyai hak yang sama. Orang yang terkena gangguan jiwa dan narkoba berhak mendapatkan kesem buhan dan diperlakukan seperti manusia pada umumnya atau istilah umumnya memanusiakan manusia.

Fenomena dan banyaknya orang yang terkena gangguan jiwa dan penyalahguna narkoba membuat Kyai Masrur menjadikan PP Al-Qodir sebagai tempat pengobatan bagi gangguan jiwa dan pecandu narkoba. Penyebaran Islam yang ramah dengan menggunakan aspek humanis menjadi salah satu konsep pengajaran yang dilakukan di pondok tersebut. Misinya menjadikan Islam sebagai agama yang dicintai oleh seluruh alam dan dapat menyejahterakan orang lain dengan ilmu yang didapat dari mengaji.

\section{E. Strategi Rehabilitasi Penyalahguna Narkoba Melalui Pendekatan Keagamaan}

Dalam konsep Islam sebuah proses rehabilitasi lebih dikenal dengan istilah terapi, dengan menggunakan prinsip "Berobat" dan "Bertaubat". Berobat berarti

\footnotetext{
${ }^{21}$ http://www.tempo.co/read/news/2013/04/10/063 472401/Pengguna-Narkoba-di-Indonesia-Tembus-4Juta-Orang, diakses pada 09 Januari 2016.
}

pasien menjalani proses pember sihan diri (Detoksifikasi) dari racun obat terlarang, sedangkat berataubat memiliki makna memohon ampun atas segala kesalahan kepada Allah SWT dan berjanji tidak akan mengonsumsi obat terlarang kembali.

Sebagaimana telah diatur dalam Undang-Undang Narkotika Nomor 35 Tahun 2009 (UU No.35 tahun 2009) memiliki tujuan ketersediaan kepentingan kesehatan dan ilmu pengetahuan, pencegahan penyalahgunaan narkotika, serta pemberantasan peredaran gelap narkotika. Penegakan hukum terhadap tindak pidana narkotika telah banyak dilakukan oleh aparat penegakan hukum dan telah banyak mendapatkan putusan hakim di sidang pengadilan. Penegakan hukum ini diharapkan dapat menangkal merebaknya peredaran perdagangan narkotika.

Menurut UU RI No. 35 Tahun 2009, ada dua jenis rehabilitasi, yaitu: Rehabilitasi Medis adalah suatu proses kegiatan pengobatan secara terpadu untuk membebaskan pecandu dari ketergantungan narkotika. Rehabilitasi Sosial adalah suatu proses kegiatan pemulihan secara terpadu, baik fisik, mental maupun sosial, agar bekas pecandu narkotika dapat kembali melaksanakan fungsi sosial dalam kehidupan masyarakat. ${ }^{22}$

Pusat atau Lembaga Rehabilitasi yang baik haruslah memenuhi persyaratan antara lain: (1) Sarana dan prasarana yang memadai termasuk gedung, akomodasi, kamar mandi/WC yang higienis, makanan dan minuman yang bergizi dan halal, ruang

\footnotetext{
${ }^{22}$ Undang-Undang No. 35 Tahun 2009 Tentang Narkotika.
} 
kelas, ruang rekreasi, ruang konsultasi individual maupun kelompok, ruang konsultasi keluarga, ruang ibadah, ruang olahraga, ruang keterampilan dan lain sebagainya; (2) Tenaga yang profesional (psikiater, dokter umum, psikolog, pekerja sosial, perawat, agamawan/ rohaniawan dan tenaga ahli lainnya/instruktur). Tenaga profesional ini untuk menjalankan program yang terkait; (3) Manajemen yang baik; (4) Kurikulum/program rehabilitasi yang memadai sesuai dengan kebutuhan; Peraturan dan tata tertib yang ketat agar tidak terjadi pelanggaran ataupun kekerasan. $^{23}$

Proses rehabilitasi juga dilakukan di Pondok Pesantren sebgaiaman di Ponpes AlQodir yang banyak menangani masalah gangguan jiwa dan pecandu narkoba. Dalam pandangan keagamaan lebih dikenal dengan istilah "Terapi" dalam upaya penanggulangannya. Terapi yang digunakan pak kyai untuk merubah prilaku pasien yang tidak normal menjadi normal, sehingga pasien benar-benar dapat menyesuaikan diri. Adapun terapi-terapi yang dilakukan sebagai berikut:

1. Menyebut Pasien Dengan Nama Santri; Merupakan metode guna menjadikan pasien sama dengan santri normal lainya. Metode ini menerapkan aspek psikologi sehingga tidak ada jurang pemisah antar santri yang dalam tahap rehabilitasi dengan santri yang sehat pada umumnya. Pembiasaan yang dilakukan pak kyai ini menjadikan obat tersendiri dalam aspek penyembuhan.

${ }^{23}$ Balai Rehabilitasi Narkoba, Tinjauan Rehabilitasi Narkoba, (Yogyakarta: Kunci, 2015), hlm 18.
2. Melatih Santri Gangguan Jiwa Dengan Pola Hidup Orang Normal; Metode ini menekankan pasien untuk melakukan aktivitas selayaknya santri biasa: mencuci baju, makan, sholat jama'ah, dzikir, gotong royong, dll. Secara psikologis pasian akan lebih termotivasi karena merasa dibutuhkan dan sama dengan santri lainya. Manfaat lain bagi pasian menjadi mudah dalam bersosialisasi dengan teman-temannya.

3. Terapi Lingkungan; Lingkungan sangatlah berpengaruh terhadap situasi dan kondisi seseorang. Sebagai contoh dalam terapi sholat dan dzikir, seorang pasian dibiarkan sholat berjama'ah seperti santri biasa walaupun dia tidak sholat melainkan hanya berdiri saja, namun lama kelamaan mereka akan sadar dengan sendirinya.

Terapi lingkungan ini lebih bersifat mengalir sesuai dengan kegiatan santri, sebagaimana kegiatannya sebagai berikut: Dini hari dimulai dengan terapi mandi kemudian dilanjutkan dengan terapi sholat dan dzikir, kemudian melakukan aktivitas seperti biasannya hingga siang terdapat terapi peralihan sampai di malam harinya diadakan terapi dzikir. ${ }^{24}$

Serangkaian kegiatan dalam konteks rehabilitasi ini tidak berdiri sendiri, tetap melakukan kerjasama dengan dokter, psikiater, psikolog dan sosial worker. Secara umum dalam proses rehabilitasi paling tidak meliputi beberapa tahap, yaitu: Penerimaan Awal (pendataan data diri pasien), Detoksifikasi (proses pelepasan racun dari

\footnotetext{
${ }^{24}$ Wawancara dengan Pengurus Pondok Pesantren Al-Qodir, pada tanggal 1 Januari 2016.
} 
tubuh pasien), Pra Rehabilitasi, Rehabilitasi Sosial (meliputi Rehabilitasi fisik, sosial, spiritual maupun mental), Ressosialisasi, dan Terminasi. ${ }^{25}$

Mereka yang mondok di pesantren rehabilitasi agar mereka kembali sehat dalam arti:

a. Sehat Jasmani/fisik (biologi); Secara jasmani ataupun fisik seorang pasien tidak lagi terdapat racun yang berbahaya dalam tubuhnya, sehingga setelah proses detoksifikasi diharapkan pasien lebih menjaga dalam berteman dan lingkungannya.

b. Sehat Jiwa (psikologi); Sehat jiwa memiliki konotasi sehat psikis atau mental pasien. Terkadang dalam proses rehabilitasi tidak sedikit pasien yang mengalami gangguan jiwa, depresi, frustasi, lupa ingatan, dll. Sehingga kesehatan jiwa ini menjadi salah satu tujuan dalam keberhasilan rehabilitasi.

c. Sehat Sosial (adaptasi); Sehat secara sosial memiliki artian berkomunikasi dengan orang lain dalam fungsi sosialnya. Sebagai remaja selayaknya Ia memiliki teman untuk bercerita, bersenda gurau, bermain dll. Banyak dari pasien yang tidak mendapatkan kebahagiaan itu.

d. Sehat Rohani/keimanan (spiritual); Kesehatan yang terakhir adalah sehat rohaniah. Kesehatan ini merupakan ciri khas yang diunggulkan dari pesantren, yang mana pasien tidak hanya sembuh dalam hal tidak menggunakan kembali, namun pasien sudah mengerti kewajibankewajiban sebagai seorang yang beriman.

\section{F. KESIMPULAN}

Perkembangan teknologi menjadi tanda munculnya globalisasi, akses terhadap infromasi sudah semakin mudah didapat baik dari kalangan remaja hingga anak yang masih dibawah umur sekalipun. Fenomena ini memunculkan efek yang negatif bagi generasi penerus bangsa, memerlukan pengawalan dari orang dewasa guna mendampingi sang anak dalam proses perkembangannya. Tidak dapat dipungkiri efek negatif yang bermunculan seperti pengaruh obat-obat terlarang yaitu narkoba.

Rehabilitasi secara umum memiliki pengertian upaya untuk mengobati pasien penyalahguna narkoba untuk tidak lagi mengonsumsi obat-obat tersebut dan menjadi sehat. Rehabilitasi setidaknya meliputi rehabilitasi medis (melibatkan Dokter) dan rehabilitas sosial (melibatkan Psikiatri, Social Worker). Sedangkan rehabilitasi menurut pandangan agama memiliki tujuan yang menjadi target dalam kesembuhan pasien, yaitu Sehat Jasmani (Biologik), Sehat Jiwa (Psikologik), Sehat Sosial (Adaptasi), Sehat Rohani (Spiritual). Menajdi ciri khas penyembuhan dalam perspektif agama menjadikan sehat rohani, karena seorang pasien diharapkan tidak hanya sembuh jasmaninya saja juga harus mengerti kewajiban sebagai orang yang beriman.

\footnotetext{
${ }^{25}$ Eko Prasetyo,Mengapa Seorang Pecandu Harus Di Rehabilitasi, presentasi pada tanggal 20 Desember 2015.
} 


\section{DAFTAR PUSTAKA}

Arikunto, Suharsimi. 2006. Prosedur Penelitian: Suatu Pendekatan Praktek, Jakarta: Rineka Cipta.

Bossard, Andre. 1988. "Drug Traffickers: Multiple Profiles" dalam Ed Dennies Rowe Internasional Drug Trafficking, Chicago: OICJ.

Badan Narkotika Nasional, 2012. Narkotika Dalam Pandangan Agama, Jakarta: BNN.

Balai Rehabilitasi Narkoba, 2015. Tinjauan Rehabilitasi Narkoba, Yogyakarta: Kunci.

Basrowi dan Suwandi, (eds). 2008. Memahami penelitian kualitatif, Jakarta: Rineka Cipta.
Departemen Agama RI. 2009. AL-Qur'an dan Terjemahnya, Jakarta: PT Sygma Examedia.

Hamzah, Andi. 1994. Kejahatan Narkotika dan Psikotropika, Jakarta: PT Karya Unipress.

Hawari, Dadang. 2008. Terapi (Detoksifikasi) dan Rehabilitasi (Pesantren) Mutakhir Pasien Naza, Jakarta: UI Press.

Willy, Heriadi. 2005. Brantas Narkoba Tak Cukup Hanya Bicara, Yogyakarta: UII Press.

Moleong, Lexy J. 1990. Metode Penelitian Kualitatif, Bandung: Rosdakarya. 